\title{
Effects of akidi (Vigna unguiculata sub spp. Sesquipedalis) planting density on growth, yields and land use efficiency of akidi/cassava intercrop \\ T. U. U. Ekpo, ${ }^{1}$ and N. U. Ndaeyo ${ }^{2}$ \\ ${ }^{1}$ Agricultural Education Department, College of Education Afaha Nsit, Akwa Ibom State, Nigeria. \\ ${ }^{2}$ Department of Crop Science, University of Uyo, Uyo, Nigeria.
}

\begin{abstract}
Field experiment was conducted at the Teaching and Research Farm, College of Education, Afaha Nsit, Akwa Ibom State, Nigeria to determine the effects of akidi (vegetable cowpea) planting density on growth, yields and productivity of akidi /cassava intercropping system in 2008 and 2009 planting seasons. The experiment was laid out in randomized complete block design with three replicates. Treatments were seven akidi populations of 20,000, 30,000, $40,000,50,000,60,000,70,000$ plants/ha and a sole cassava. Akidi was also planted sole and in intercropped with cassava. Results indicated that the average plant height of 180.66 and $180.74 \mathrm{~cm}$ obtained from the akidi plots at 60,000 and 70,000 plants/ha was significantly $(\mathrm{P}<0.05)$ higher than the average of $170.12 \mathrm{~cm}$ obtained from sole cassava. Similar trend was also observed in cassava leaf area index. A significantly $(\mathrm{P}<0.05)$ lowest number of pods/plant (7.37) was obtained from the intercropped plots of akidi (70,000 plants/ha). Dry seed yield of $313.00 \mathrm{~kg} / \mathrm{ha}$ obtained from the sole plots of akidi $(60,000$ plants/ha) was significantly higher than $284.97 \mathrm{~kg} / \mathrm{ha}$ obtained from intercropping akidi at the same planting density. Akidi plots at 60,000 and 70,000 plants/ha produced significantly higher cassava tuberous root yields than the yields obtained from sole cassava and from the plots of other akidi densities in the intercrop. Although akidi at 70,000 plants/ha produced the highest cassava tuberous root yield advantage by $30.1 \%$ over sole cassava; the highest land equivalent ratio (2.34) was however obtained from akidi plots at 60,000 plants/ha. From this study, it appears that integration of optimum akidi density $(60,000$ plants/ha) in cassava intercrop can enhance cassava growth, tuberous root yield and increased land use efficiency.
\end{abstract}

Keywords: Akidi, Cassava, Intercrop, planting density, yields, land use efficiency.

\section{INTRODUCTION}

Cassava is a popular energy food in most of the tropics and has replaced yam and cocoyam as the number one carbohydrate staple and is said to provide up to $40 \%$ of all the calories consumed in Africa (Udoh et al., 2005). Nigeria is the largest world producer of cassava with about 34 million metric tonnes. The leading position in Nigeria in cassava root yields is however, attributed to increase in hectarages of production over the years (FAO, 2004). Generally, per hectare crop yield obtained by the small holder farmers in Nigeria is still low compared to those from researcher managed fields (Alimi and Manyong, 2000). This explains why many Nigerians are unable to meet their daily food needs (Benson et al, 2003).

Farmers still practice intercropping systems for a number of reasons including yield advantage per hectare among others (Buhler, 2002). The low cassava yield in Nigerian Agriculture has been partly attributed to incompatibility of crop combinations in the intercropping system among other factors. Umanah (2005) and Bassey et al. (2001) reported that farmers in the humid zone of Nigeria combined more than three crops among which are maize, melon, pepper and cocoyam with cassava as based crop.

This crop combination results in competitiveness among the growing crops for available limited resources. While cereals are commonly intercropped with legumes for crop yield enhancement in Northern Nigeria; research reports on cassava being intercropped with legumes is scarce in the rainforest zone of Nigeria. However, Njoku and Muoneke (2008) reported that cassava yield in the rainforest zone of Southeastern, Nigeria was found to increase with increase in cowpea density up to 80,000 plants/ha. Though information on akidi intercropped with cassava is limited in Nigeria, it is believed that the crop has great potentials to control weed and increase crop yield. Yield advantages were gained 
by intercropping maize with akidi in Umudike, Nigeria (Okpara, 2000)

Although cassava can be successfully grown on marginal soils, giving reasonable yields where many other crops have failed (IITA, 1997); it does optimally in fertile soils well endowed with nitrogen and phosphorus (Ibia and Udo, 2009). Akidi like other edible leguminous crops have the potentials to improving physical, chemical and microbiological properties of the soil and thereby boosting subsequent crop yield (Maccoll, 1990). Such crops have been recommended for fertility enhancement (IITA, 1990) and it has shown to be beneficial to the crop in association (Solubo, 2000). Since intercropping is the dominance cropping system in the country, leguminous crop in intercropping system would serve as a good opportunity to guarantee sustainable soil fertility maintenance in view of soil fertility constraints across Nigeria.

At present, soil amendments in cassava production is low and consequently the yield potentials of various improved varieties of cassava are not often attained (Njoku and Muoneke 2008). Therefore this research was undertaken to examine the optimum akidi density that would enhance growth and yields of cassava/akidi intercrop.

\section{MATERIALS AND METHODS}

Experimental site: The study was conducted at the College of Education Teaching and Research Farm, located at Afaha-Nsit, Akwa Ibom State, Nigeria. The area is located in the lowland rainforest zone of South Eastern Nigeria $\left(04^{\circ} 50^{1}-05^{\circ} 20^{1} \mathrm{~S}\right.$; $07^{\circ} 16^{1}$ $\left.08^{\circ} 10^{1} \mathrm{E}\right)$ and during the 2008 and 2009 planting seasons it receives about $2500 \mathrm{~mm}$ rainfall annually during the rainy season (March to November). The rainfall pattern is bimodal, with long (March -July) and short (September-November) rainy seasons separated by a short dry spell of uncertain length, usually in the month of August. The mean relative humidity is $78 \%$, atmospheric temperature $30^{\circ} \mathrm{C}$ and mean sunshine hour 12 . The soil was acidic coastal plain sands locally grouped under Benin formation. The site was fallowed for five years and the dominant vegetation included Chromolaena odorata, Pueraria phasioloides and Panicum maximum.

The experimental site was fallowed for four years. Soil analysis of the experimental site revealed that the soil was sandy loam with $\mathrm{pH}$ of 6.3 and of ultisol broad group classification. The experiment was carried out in 2008 and 2009.

Experimental design and treatment: Bush clearing, stumping and tillage were done manually. Each plot measured $6 \times 8 \mathrm{~m}$ and spaced $1.5 \mathrm{~m}$ apart.
The experiment was laid out in a Randomized Complete Block Design with three replicates. The treatments consisted of six Akidi populations:

$20,000,30,000,40,000,50,000,60,000,70,000$ (Plants/ha) planted sole and intercropped with cassava. The was also a cassava as a control.

The akidi used in this study was a creeping type and usually mature within $90-100$ days. The seeds were planted in the same row with cassava at $1 \mathrm{~m} x$ $1 \mathrm{~m}$ apart and the akidi density was maintained according to the treatments after thinning at 10 days after planting. Cassava (TMS 30572) was planted $1 \mathrm{~m} \times 1 \mathrm{~m}$ apart $(10,000$ plants/ha). Weeding was done at 4 and 12 weeks after planting (WAP). Fertilizer (NPK - 15: 15: 15) at $150 \mathrm{~kg} / \mathrm{ha}$ was applied to cassava at 5 WAP.

Assessment of cassava height and number of leaves per plant was done at 4, 6, 8 and 10 WAP. Leaf area index was determined at 2, 3, 4 and 5 months after planting. Cassava tuberous root yield was determined at harvest (12 months after planting). Dry seed yield and yield components of akidi (number of pods/plant, number of seeds/pod, and 100-dry seed weight) were determined at harvest (95 days after planting).

The land use efficiency of cassava/akidi intercrop was evaluated using the land equivalent ratio (LER) as described Udoh and Ndaeyo (2000). Data collected were subjected to analysis of variance and Duncan multiple range test used to compare the treatment means.

\section{RESULTS AND DISCUSSION}

Table 1 shows height and number of leaves per plant of cassava planted sole and intercrop with Akidi. Plant height and number of leaves per plant were not significantly different at 4-10 WAP. However, at harvest (12 MAP) cassava height $(178.00 \mathrm{~cm})$ obtained from the plot planted to akidi at 70,000 plants/ha was significantly $(P<0.05)$ higher than height of $169.90,170.95,172.22$ and $173.40 \mathrm{~cm}$ obtained from the plots of sole cassava and akidi at20,000, 30,000 and 40,000 plants/ha, respectively at 12 MAP in 2008. The height of $175.00 \mathrm{~cm}$ obtained from the plot of akidi $(50,000$ plants/ha) was comparable to that obtained from akidi plot at 70,000 plants/ha $(178.00 \mathrm{~cm})$ and $173.40 \mathrm{~cm}$ obtained from akidi plot (40,000 plants/ha) at 12 MAP in 2008. Similar trend was also observed in 2009. The shortest cassava plant (169.90 and $170.31 \mathrm{~cm}$ ) were obtained from the sole cassava plots in 2008 and 2009, respectively. 
Agric. Biol. J. N. Am., 2011, 2(11): 1383-1389

TABLE 1: Effects of akidi density on cassava height $(\mathrm{cm})$ and number of leaves per plant in sole and cassava/akidi intercrop in 2008 and 2009

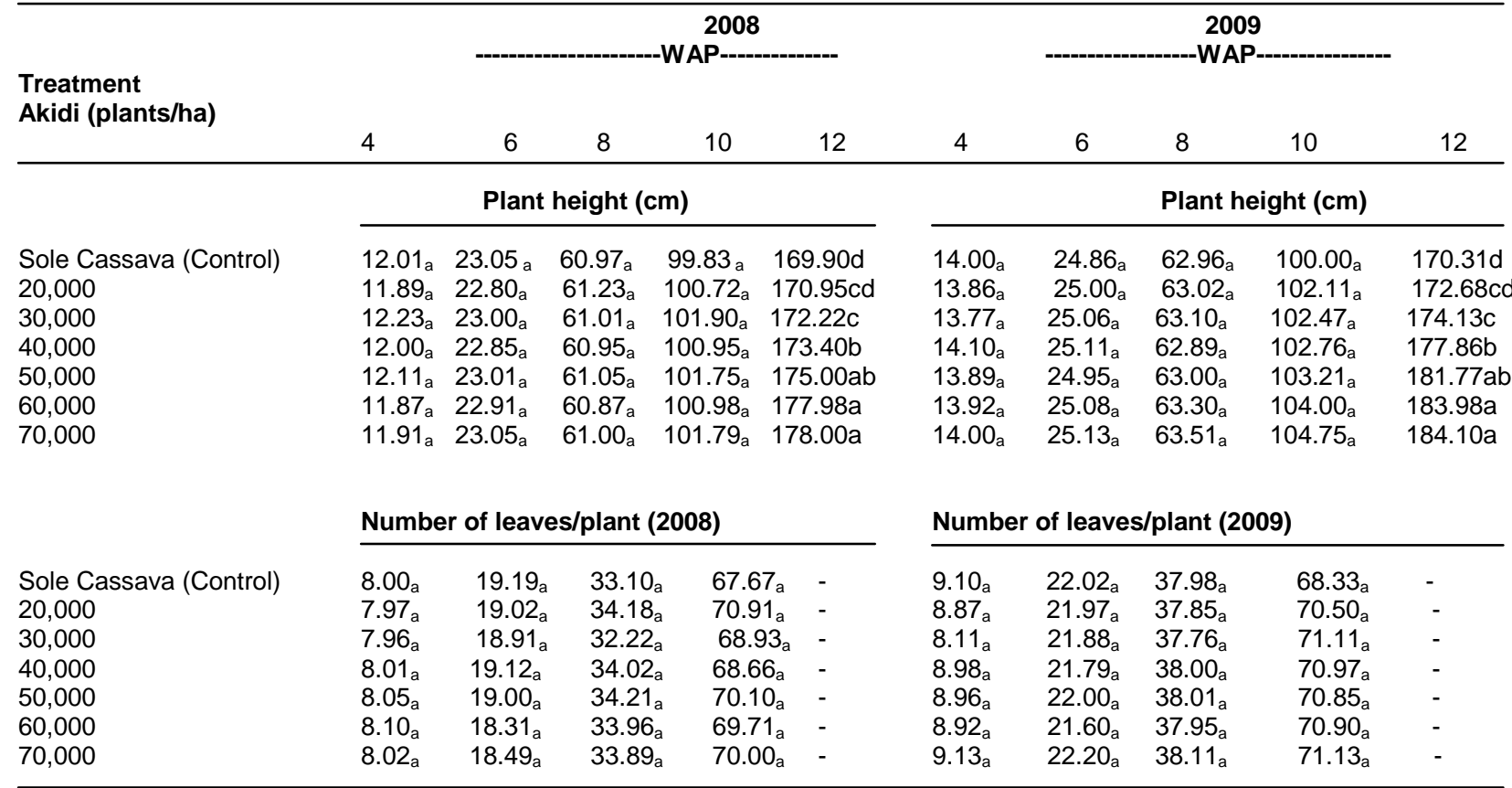

Means followed by the same letter(s) within each column of the same parameter are not significantly different by DMRT at $5 \%$ probability level.

Leaf area index was found to be significantly different at 4 and 5 MAP in both years (Table 2). The leaf area obtained from the 60,000 and 70,000 plants/ha plots were significantly $(\mathrm{P}<0.05)$ higher than the leaf area indices obtained from akidi
$(20,000$ and 30,000 plants/ha) plots and sole cassava in 2008 and 2009. The significantly lowest leaf area indices of 1.30 and 1.87 were obtained from the sole cassava plot at 4 and 5 MAP, respectively in 2008. Similar trend was also observed in 2009.

Table 2: Effects of akidi density on cassava leaf area index in sole and cassava/akidi intercrop in 2008 and 2009 planting seasons

\begin{tabular}{|c|c|c|c|c|c|c|c|c|}
\hline \multirow{2}{*}{$\begin{array}{l}\text { Treatment } \\
\text { Akidi (plants/ha) }\end{array}$} & \multicolumn{4}{|c|}{$\begin{array}{r}2008 \\
\text {-MAP--- }\end{array}$} & \multicolumn{4}{|c|}{2009} \\
\hline & 2 & 3 & 4 & 5 & 2 & 3 & 4 & 5 \\
\hline Sole Cassava (Control) & $0.48 \mathrm{a}$ & $0.88 \mathrm{a}$ & $1.30 c$ & $1.87 \mathrm{c}$ & $0.55 a$ & $0.90 \mathrm{a}$ & $1.43 c$ & $1.98 \mathrm{c}$ \\
\hline 20,000 & $0.48 \mathrm{a}$ & $0.92 a$ & $1.36 \mathrm{bc}$ & $2.03 \mathrm{bc}$ & $0.53 a$ & $0.93 a$ & $1.51 b c$ & $2.14 \mathrm{bc}$ \\
\hline 30,000 & $0.51 a$ & $0.89 a$ & $1.40 \mathrm{~b}$ & $2.10 \mathrm{~b}$ & $0.66 \mathrm{a}$ & $0.94 a$ & $1.57 \mathrm{~b}$ & $2.39 \mathrm{~b}$ \\
\hline 40,000 & $0.51 \mathrm{a}$ & $0.93 a$ & $1.48 a b$ & $2.38 \mathrm{ab}$ & $0.62 a$ & $0.94 a$ & $1.63 a b$ & $2.48 a b$ \\
\hline 50,000 & $0.49 a$ & $0.92 a$ & $1.51 \mathrm{ab}$ & $2.41 \mathrm{ab}$ & $0.63 a$ & $0.97 a$ & $1.65 a b$ & $2.52 a b$ \\
\hline 60,000 & $0.48 a$ & $0.91 a$ & $1.58 \mathrm{a}$ & $2.65 \mathrm{a}$ & $0.66 a$ & $0.96 a$ & $1.76 \mathrm{a}$ & $2.67 \mathrm{a}$ \\
\hline 70,000 & $0.50 \mathrm{a}$ & $0.90 a$ & $1.61 \mathrm{a}$ & $2.68 \mathrm{a}$ & $0.68 a$ & $0.98 a$ & $1.77 \mathrm{a}$ & $2.69 \mathrm{a}$ \\
\hline
\end{tabular}

Means followed by the same letter(s) within each column of the same parameter are not significantly different by DMRT at $5 \%$ probability level.

The number of akidi pods per plant was significantly affected in cassava/akidi intercrop than sole akidi in 2008 and 2009 (Table 3). The number of pods per plant obtained from the plots of akidi $(20,000,30,000$ and 40,000 plants/ha) were higher than the number obtained from the plants of akidi $(50,000,60,000$ and 70,000 plants/ha) in both sole and intercrop in
2008 and 2009. The sole akidi $(50,000,60,000$ and 70,000 plants/ha) plots produced a significantly $(\mathrm{P}<$ 0.05 ) higher number of pods per plant than those obtained from the intercrop plots at the same density. However, the lowest number of pods per plant was obtained from the intercropped plots of akidi (70,000 plants/ha) in 2008 and 2009. 
Agric. Biol. J. N. Am., 2011, 2(11): 1383-1389

Table 3: Effects of akidi density on akidi yield components in sole and cassava/akidi intercrop at harvest in 2008 and 2009 planting seasons

\begin{tabular}{|c|c|c|c|c|c|c|}
\hline \multicolumn{7}{|c|}{ Yield components } \\
\hline \multicolumn{7}{|c|}{ Sole } \\
\hline \multirow{2}{*}{$\begin{array}{l}\text { Treatments } \\
\text { Akidi (plants/ha) }\end{array}$} & \multicolumn{2}{|c|}{ Number of pods/ plant } & \multicolumn{2}{|c|}{ Number of seeds/pod } & \multicolumn{2}{|c|}{100 - dry seed weight (g) } \\
\hline & 2008 & 2009 & 2008 & 2009 & 2008 & 2009 \\
\hline 20,000 & $13.10 \mathrm{a}$ & $11.00 \mathrm{a}$ & $9.12 \mathrm{a}$ & $10.21 \mathrm{a}$ & $7.04 \mathrm{a}$ & $7.30 \mathrm{a}$ \\
\hline 30,000 & $13.07 a$ & $11.05 \mathrm{a}$ & $9.05 a$ & $10.17 a$ & $7.00 \mathrm{a}$ & $6.88 a$ \\
\hline 40,000 & $13.06 a$ & $11.03 \mathrm{a}$ & $9.02 a$ & $9.97 a$ & $7.01 \mathrm{a}$ & $7.11 \mathrm{a}$ \\
\hline 50,000 & $11.28 \mathrm{~b}$ & $9.95 b$ & $8.90 \mathrm{a}$ & $9.83 a$ & $6.90 \mathrm{a}$ & $6.95 a$ \\
\hline 60,000 & $10.68 \mathrm{bc}$ & $8.59 \mathrm{bc}$ & $8.88 a$ & $8.99 a$ & $6.97 a$ & $6.89 a$ \\
\hline 70,000 & $9.76 \mathrm{bcd}$ & $7.98 \mathrm{bcd}$ & $8.68 a$ & $8.95 a$ & $6.87 a$ & $6.67 a$ \\
\hline \multicolumn{7}{|c|}{ Intercrop } \\
\hline 20,000 & $13.00 \mathrm{a}$ & $10.94 \mathrm{a}$ & $8.96 a$ & $9.60 a$ & $7.19 a$ & $7.00 \mathrm{a}$ \\
\hline 30,000 & $12.98 \mathrm{a}$ & $10.91 \mathrm{a}$ & $10.85 a$ & $9.48 a$ & $7.12 \mathrm{a}$ & $6.92 a$ \\
\hline 40,000 & $12.96 \mathrm{a}$ & $10.88 \mathrm{a}$ & $8.88 a$ & $9.00 \mathrm{a}$ & $7.09 a$ & $6.88 a$ \\
\hline 50,000 & $10.17 \mathrm{c}$ & $8.21 \mathrm{c}$ & $10.79 a$ & $8.94 a$ & $6.93 a$ & $6.52 \mathrm{a}$ \\
\hline 60,000 & $9.02 \mathrm{~d}$ & $7.44 \mathrm{~d}$ & $10.76 \mathrm{a}$ & 7.98a & $6.49 a$ & $6.48 a$ \\
\hline 70,000 & $7.89 \mathrm{e}$ & $6.85 \mathrm{e}$ & $8.65 a$ & $7.87 a$ & $6.18 a$ & $6.25 a$ \\
\hline
\end{tabular}

Means followed by the same letter(s) within each column of the same parameter are not significantly different by DMRT at $5 \%$ probability level.

Dry akidi seed yields obtained from sole plots of $20,000,30,000$ and 40,000 plants/ha were not significantly different from the yields obtained from the respective intercrop plots in 2008 and 2009 (Table 4). Seed yields ( 333.29 and $324.93 \mathrm{~kg} / \mathrm{ha}$ ) obtained from sole akidi plots $(70,000$ plants/ha) in 2008 and 2009 respectively were significantly higher than the seed yields obtained from the intercrop plots of akidi (40,000 plants/ha) and other akidi densities in sole and intercropped plots. Similarly, the dry seed yield of $313.37 \mathrm{~kg} / \mathrm{ha}$ obtained from the plots of sole akidi $(60,000$ plants/ha $)$ was significantly higher than $284.97 \mathrm{~kg} / \mathrm{ha}$ obtained from the plots of intercrop akidi at the same density over an average of two years planting.

The plots of akidi $(60,000$ and 70,000 plants/ha) produced significantly higher cassava tuberous root yields of 19.88 and $19.92 \mathrm{t} / \mathrm{ha}$, respectively than sole yield and yields obtained from the plots of other akidi densities on average of two years planting (Table 5). The cassava tuberous root yields of 17.35 and 19.78 $\mathrm{t} /$ ha obtained from the plots of akidi $(40,000$ plants/ha) in 2008 and 2009, respectively were at par with the yields obtained from the plots of akidi $(30,000$ and 50,000 plants/ha). The lowest average yield (13. $93 \mathrm{t} / \mathrm{ha}$ ) was obtained from the sole cassava plots on two years average yields. This yield was not significantly different from the average of $13.96 \mathrm{t} / \mathrm{ha}$ obtained from the plots of intercropped akidi (20,000 plants/ha) on average of two years planting.

The relative yield $(R Y)$ and land equivalent ratio (LER) for cassava increased with increase in akidi density from 20,000 - 60,000 plants/ha (Table 5). The RY and LER for cassava obtained from akidi plots (60,000 plants/ha) were 0.91 and 2.34, respectively. However, the RY and LER for cassava declined to 0.90 and 2.33 respectively with increase in akidi density up to 70,000 plants/ha. The RY obtained for akidi decreased with increase in akidi density. The range was 0.94 from akidi plot 20,000 plants/ha plots to 0.90 obtained from the 70,000 plants/ha. 
Agric. Biol. J. N. Am., 2011, 2(11): 1383-1389

Table 4: Effects of akidi density on dry akidi seed yield (kg/ha) in sole and cassava - akidi intercrop in 2008 and 2009

\begin{tabular}{|c|c|c|}
\hline \multicolumn{3}{|c|}{ Dry akidi Seed Yield (kg/ha) } \\
\hline \multirow[b]{2}{*}{$\begin{array}{l}\text { Treatments } \\
\text { Akidi (Plants/ha) }\end{array}$} & 2008 & 2009 \\
\hline & & \\
\hline & \multicolumn{2}{|c|}{ Sole } \\
\hline 20,000 & $131.31 \mathrm{~h}$ & $129.31 \mathrm{~h}$ \\
\hline 30,000 & $200.05 \mathrm{~g}$ & $200.64 \mathrm{~g}$ \\
\hline 40,000 & $260.62 \mathrm{f}$ & $248.91 \mathrm{f}$ \\
\hline 50,000 & $305.62 \mathrm{~d}$ & $278.51 \mathrm{~d}$ \\
\hline 60,000 & $320.88 \mathrm{c}$ & $305.85 \mathrm{c}$ \\
\hline \multirow[t]{2}{*}{70,000} & $333.29 \mathrm{a}$ & $324.93 \mathrm{a}$ \\
\hline & \multicolumn{2}{|c|}{ Intercrop } \\
\hline 20,000 & $125.91 \mathrm{~h}$ & $120.34 \mathrm{~h}$ \\
\hline 30,000 & $194.73 \mathrm{~g}$ & $191.83 \mathrm{~g}$ \\
\hline 40,000 & $253.09 \mathrm{f}$ & $216.87 f$ \\
\hline 50,000 & 295.17 de & 245.01de \\
\hline 60,000 & $308.87 \mathrm{~d}$ & $261.06 \mathrm{~d}$ \\
\hline 70,000 & $317.91 \mathrm{~b}$ & $276.98 \mathrm{~b}$ \\
\hline
\end{tabular}

Means followed by the same letter(s) within each column of the same parameter are not significantly different by DMRT at $5 \%$ probability level.

TABLE 5: Effects of akidi density on cassava tuberous root yield and land equivalent ratio (LER) in 2008 and 2009

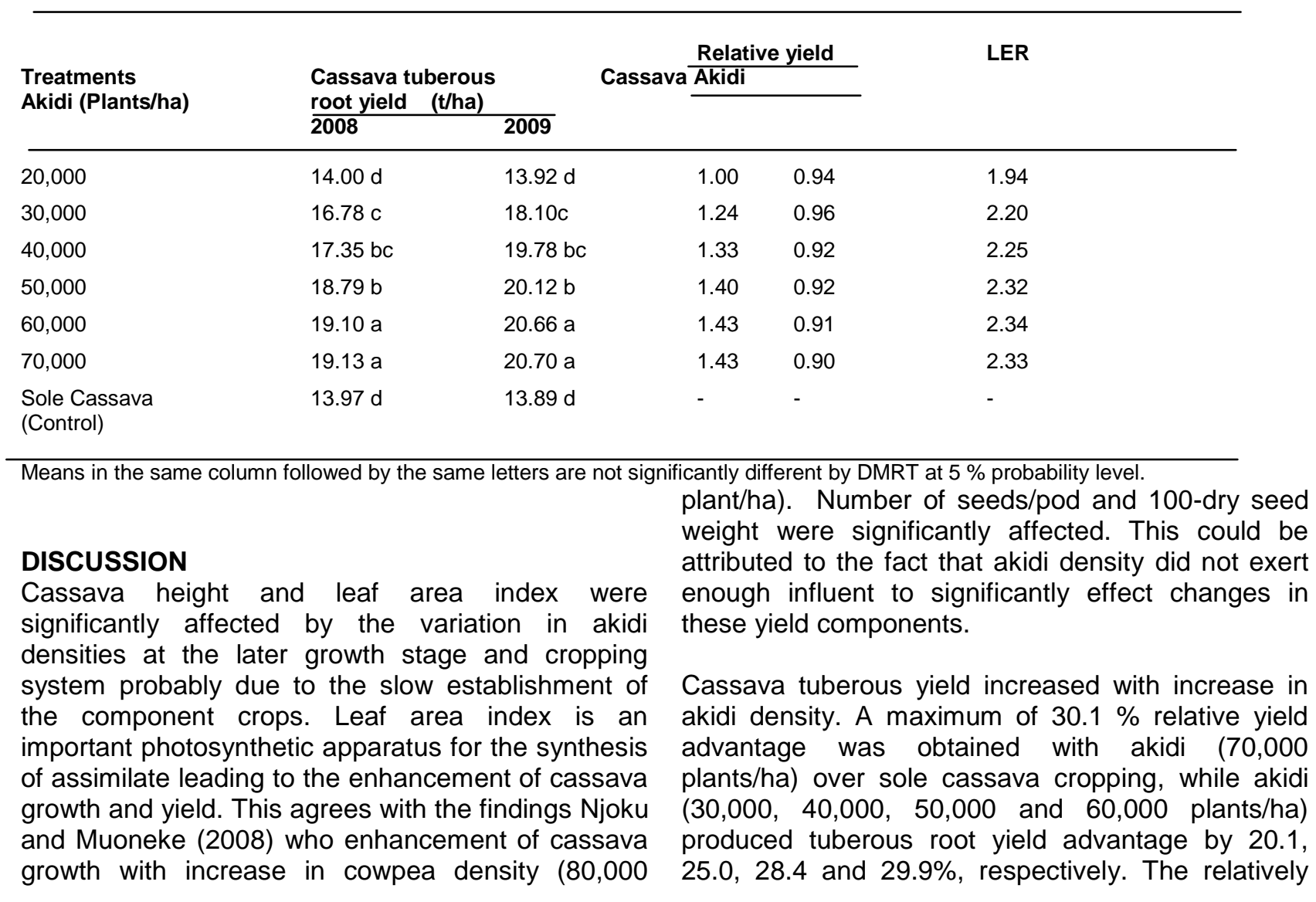


high cassava tuberous root yield from the plot of akidi (70,000 plants/ha) could be attributed to the integration of legume crop population which might have enhanced soil fertility status (Maccoll, 1990). Such crop when planted together has been known to have beneficial effect on the based crop in association (Sobulo, 2000). The potential to integrate legumes into existing cropping systems in the tropics is high (Kumwenda et al., 1996). In addition, the high population of akidi might reduce the weed pressure at the critical period of cassava growth which is within 3-4 months (Akobundu 1987; Chikoye et al. 2000). Findings from this study agrees with that of Njoku and Muoneke (2008) that the highest cassava tuberous root yield was obtained from the plot of the highest density of cowpea $(80,000$ plants/ha).

On the other hand, increasing the akidi density in the intercrop to $50,000,60,000$ and 70,000 plants/ha reduced akidi seed yield by $7.5,9.1$ and $9.6 \%$, respectively compared with the sole yield. This could be attributed to the intra-specific competition due to crop population in the intercrop which reduced the number of Akidi pods/plant. This finding can also be ascribed to competition for limited nutrients, space and light as observed by Fininsa (1997); although not specifically determined in this investigation. The relative low maize yield in maize/sweet potato intercrop was reported by Eneji et al. (1997). Similarly, IITA (1985) reported that melon performed poorly in a cropping system with cassava-maize and yam but improved the yield of other component crops.

The RY and LER in cassava/akidi intercrop increased with increase in akidi density up to 60,000 plants/ha and became constant with increase to 70,000 plants/ha. This demonstrated the productivity of intercrop with increase in akidi density. Fininsa (1997) also reported high LER with bean population of 78,947 and maize intercrop. The LER for akidi decreased in descending order reflecting the decrease in intercrop productivity with increase in akidi population up to 70,000 plants/ha. The plot with the population of akidi $(60,000$ plants/ha) gave the highest LER (2.34) indicating the advantage of intercropping over sole cropping and other densities (Onwremadu et al., 2008).

\section{CONCLUSION}

Integration of optimum akidi density of 60,000 plants/ha in cassava based cropping improved cassava growth, tuberous root yield and increased land productivity. This system could improve the soils status provide sustainable proteinous food crop and income to farmers.

\section{REFERENCES}

(1) Akobundu, I. O. 1987. Weed Science in the Tropics: Principles and Practices. New York, Wiley and Sons 522pp.

(2) Alimi, T and Manyong, V. M. 2000. Partial Budget analysis for on-Farm Research, IITA Research Guide 65:1-51.

(3) Bassey, A. E., Akpan, E. E. and Asuquo, P. E. 2001. On Farm Evaluation of the Economics and Acceptability of Newly Released Cassava Cultivars (NR 8082 and 8083). In Proceedings of the 16th Annual Zonal Research Extension, Farmer Input Linkage Systems Workshop South East South Zones of Nigeria held at Uyo, Nigeria on 19th- 23rd November, 2001.

(4) Buhler, A. G. 2002. Challenges and Opportunities for Integrated Weed Management. Weed Science, 50: 273-280

(5) Benson, T; Palmer, T. and Johnson-Welch, C. 2003. Agriculture-Nutrition Advantage Project Document. International Food Policy Research Institute. (IFPRI), Washington, DC. pp75.

(6) Chikoye, D., Manyong, V. M., Carsky, R. J., Ekkeleme, F., Gbehounou, G. and Ahancehede, A. 2002. Response of Speargrass to Cover Crops Integrated with Hand-Weeding and Chemical control in Maize and Cassava. Crop Protection, 21;145-156.

(7) Eneji, A. E; Agboola, A. A. and Ubi, B. E. 1997. Effect of Farm Yard Manure and NPK Fertilizers on Growth and Yield of Intercropped Maize and Sweet Potato in South-Western Nigeria. Revista di Agricoltura Subtropicale Tropicale, 91 (1): 64-78.

(8) Fininsa, C. 1997. Effects of Planting Pattern, Relative Planting Date and Intra-Row Spacing on a Haricot Bean/Maize Intercrop. Africa Crop Science Journal, 5 (1): 15-22.

(9) FAO (Food and Agricultural Organization) 1993. Produce yearbook, FAO Statistics series, 47 (117): 177.

(10) Ibia, T. O. and Udo E. J. 2009. Guide to Fertilizer Use for Crops in Akwa Ibom State, Nigeria Lagos, Sibon Books Limited, 104 pp.

(11) IITA (International Institute of Tropical Agriculture) 1985. Farming Systems Progress Research Highlights, 1981-1984, (IITA) Ibadan, Nigeria.

(12) IITA (International Institute of Tropical Agriculture) 1990. Cassava in Tropical Africa. A Reference Manual pp 6-7.

(13) IITA (International Institute of Tropical Agriculture) 1997. Annual Report. (IITA) Ibadan, Nigeria, pp 6631. 
(14) Kumwenda, J. D., Waddington Snap, J. S. R., Jones, S. S., R. B. and Blackit, J. 1996. Soil

Fertility Management Research for the Maize Cropping Systems of Small Holders in Southern Africa. $A$ Review CMMYT, Mexico pp 96-102.

(15) Maccoll, D. 1990. Studies on Maize at Bunda, Malawi. Yield in Rotation with Pasture Legumes. Experimental Agriculture, 26: 263-271.

(16) Njoku, D. N. and Muoneke, C. O. 2008. Effects of Cowpea Planting Density on Growth, Yield and Productivity of Component Crops in Cowpea/Cassava Intercropping System. Journal of Tropical Agriculture, Food, Environment and Extension, 7, (2):

(17) Okpara, D. A. 2000. Growth and Yields of Maize and Vegetable Cowpea as Influenced by Intercropping and Nitrogen Fertilizer in Lowland Humid Tropics. Journal of Sustainable Agriculture.
(18) Onweremadu, E. U., Ibeawuchi, I. I. and Duruigbo, C. I. 2008. Land evaluation and productivity of organically-fertilized crop mixtures in a degraded tropical soil. Nature and Science, 6 (1): 34-44.

(19) Udoh, A. J. and Ndaeyo, N. U. 2000. Crop productivity and land use efficiency in cassava maize systems as influenced by cowpea and melon populations. Tropical Agriculture (Tinidad), 77 (3): 150-155

(20) Udoh, D. J., Ndon, B. A., Asuquo, P. E. and Ndaeyo, N. U. 2005. Crop production techniques for the tropics. Concept publications Limited, Lagos, Nigeria. $442 \mathrm{pp}$.

(21) Umanah, E. E. (2005). Cassava: Production, Utilization and Trade. Uyo EMSEL Group pp 31.

(30) Sobulo, R. A. (2000). Fertilizer Use and Soil Testing in Nigeria. In M. O. Akoroda (ed). Agronomy in Nigeria pp. 195-201. 